\title{
Erratum to: The unconventional secretion of stress-inducible protein 1 by a heterogeneous population of extracellular vesicles
}

\author{
Glaucia N. M. Hajj • Camila P. Arantes • Marcos Vinicios Salles Dias • Martín Roffé • \\ Bruno Costa-Silva • Marilene H. Lopes • Isabel Porto-Carreiro • Tatiana Rabachini • \\ Flávia R. Lima · Flávio H. Beraldo · Marco A. M. Prado · Rafael Linden · Vilma R. Martins
}

Published online: 25 May 2013

(C) Springer Basel 2013

\section{Erratum to: Cell Mol Life Sci}

DOI 10.1007/s00018-013-1328-y

Unfortunately one of the co-author's name was incorrectly published in the original publication. The name of the author should read as Marco A. M. Prado instead of Prado MMA.

The online version of the original article can be found under doi:10.1007/s00018-013-1328-y.

G. N. M. Hajj · M. V. S. Dias · M. Roffé · B. Costa-Silva ·

V. R. Martins $(\bowtie)$

International Research Center, A.C. Camargo Hospital,

Rua Taguá 540, São Paulo 01508-010, Brazil

e-mail:vmartins@cipe.accamargo.org.br

G. N. M. Hajj · M. V. S. Dias · M. Roffé · B. Costa-Silva

V. R. Martins

National Institute for Translational Neuroscience and National

Institute of Oncogenomics, São Paulo, Brazil

C. P. Arantes

Department of Biochemistry, Chemistry Institute,

University of São Paulo, São Paulo, Brazil

M. H. Lopes

Department of Biomedical Sciences, University of São Paulo,

São Paulo, Brazil
I. Porto-Carreiro $\cdot$ R. Linden

Instituto de Biofisica Carlos Chagas Filho, Federal

University of Rio de Janeiro, Rio de Janeiro, Brazil

T. Rabachini

Ludwig Institute for Cancer Research, São Paulo,

Brazil

\section{F. R. Lima}

Instituto de Ciências Biomédicas, Federal University of Rio de Janeiro, Rio de Janeiro, Brazil

F. H. Beraldo - M. A. M. Prado

Department of Anatomy and Cell Biology and Department of Physiology and Pharmacology,

Robarts Research Institute, University of Western Ontario,

London, Canada 